\title{
WOMEN'S SUFFRAGE IN THE ELECTION OF THE PANDEGLANG REGENT YEARS 2015
}

\author{
Suwaib Amiruddin \\ Lecturer Of Sociology And Political Science \\ Universitas Sultan Ageng Tirtayasa \\ Serang, Indonesia
}

\begin{abstract}
Indonesia women's multiple roles as servants on Family Affairs, also participate in development activities. In the political activity, women have equal rights in participation in election voice conveys. The study focused on how the right women's participation on the Binuangen, in the election of the Regent of Pandeglang. The method used was qualitative. Data retrieval is performed observation, interview and dokumnetasi on women who have voting rights in the fishing village of Panimbang. The research found that the political participation of women in elections in Panimbang, pandeglang more emphasis because consciousness is active in political activities. Although women were not involved in the campaign activities and socialization of prospective Regional head. The liveliness of the women in the elections of fishermen can be seen by the existence of a willingness to register as voters. While the driving factor, at the start of the existence of consciousness choose as hoping the onset of changes.
\end{abstract}

Keywords-elections, suffrage, women

\section{INTRODUCTION}

Women actually been proven long ago to compelled in devoted themself based on expertise and their ability to build this nation. The demands of the times and the needs of the country and nation in progress, any women participate in filling and advancing the independence of Indonesia both before and after independence. The position of women in the cultural structure of society Indonesia, has demands as servants in the family. Because of it, then the women have an absolute obligation and necessity to devote time and energy to their family.

Cultural conditions, that the dual role of indonesia women's as servants in Family Affairs, also participate in development activities. The participation of women, then women's activity has a dual role as partners on equal footing in terms of development activities. Although women already involved has the role double but still found, the gap in terms of access rights of self-actualization and profession, especially in terms of position in the political scene when compared with men.

The condition of the political situation in the Indonesia, since the reform era. the position of women in politics in the Constitution get appreciation and support directly to actively participate directly taking part in practical politics. As the constitutional mandate contained in articles 55 and 56 of the ACT No.8 -Year 2012 about legislative elections mandated by at least 30 percent of women in the legislative candidate list and at least one woman among the three legislative candidates. That reinforcement, to mandates about $30 \%$ of women involved in practical political activities. Through the support of legislation, political parties are obliged to representation in the management of political party and simultaneously provide the motivation for women to plunge directly in politics.

Political parties have the obligation to provide opportunities for women so that since the reform era, women already involved in many activities of the nomination of the members of the legislative. Through the nomination, then the existence of women is required to be involved in practical, so that many are directly involved to run for regional head either as regent or governor.

The presence of women in Indonesia since the reform era is actually many demands to engage in a variety of roles, both services as well as practitioners. The demands of women in various sectors have penetrated into strategic decision making and become top leaders in various sectors. The number of women who become heads of regions from among the women, provide evidence that women during this already able to compete in the scramble for seats of power, especially as the head of the region.

In reality it was found in Banten Province from 8 cities and districts that have been appointed a regional head from among women. Even Banten was once led by a female governor of Ratu Atut Chasanah, Regent of Serang Hj Ratu Tatu Chasanah, the mayor of South Tangerang Airin, Regent Lebak Hj, Iti Oktavia Jayabaya and regional head election simultaneously in 2015, regent Pandeglang elected a woman becomes regent that is Irna Narulita. Based on that reality, actually in Banten Province there are four women elected to head region.

This fact shows that the representation of women occupying the position of regional heads in Banten Province is already around $50 \%$ of the total districts and cities in Banten. This research is not focused on women's election in regent positions, but this study focuses on women's participation in voting and voting rights in Pandeglang district head elections held in 2015. Through that focus will reveal the related How political participation and the factors driving women in the election of regional heads in Pandeglang District. 


\section{LITERATURE REVIEW}

\section{A. The involvement of women's suffrage}

The general election is the media and people's involvement in the mechanism of democracy to determine a strategic political decision, in which the voice of every people is manifested in the form of suffrage which is a form of social contract between the State and the people. One aspect of the policy of the Central Government in the framework of empowering democracy in Indonesia is the involvement of women in politics in accordance with Act No. 14-year 2004 is the implementation of the election of Direct Election of Regents / Mayors and Deputy Regents / Mayors organized by the organizers of general elections mandated entirely by Regional and Provincial Election Commission (KPUD).

The election of the head of the province according to the Government Regulation No. 6 of the year 2005 regarding Election, Appointment and dismissal of the endorsement, the head of a region and Deputy Head of the region is as mentioned in article 1 paragraph 1 that the election of the head and Deputy Head of a Region hereinafter referred to as the election is a means of implementing the sovereignty of the people and Province/region or district/city based on Pancasila and the Constitution of the Republic of Indonesia year 1945 to elect the head of the region and Deputy Head of the regional.

\section{B. Political participation}

Ramlan Surbakti provides a brief definition of political participation as a form of ordinary citizen participation in determining all decisions that affect or affect his life (Surbakti, 1999: 140). While Milbrath and Goel (Surbakti 1999: 143) distinguish participation into the following categories: First, apathy. It means people who do not participate and withdraw from the political process. Second, the spectator. That is, people who have at least voted in elections. Third, the gladiator. It means those who are actively involved in the political process, ie communicators, specialists make face-toface contact, party activists and campaign workers and community activists. Fourth, critics, namely in the form of unconventional participation. Budiarjo (2008: 136) that the behavior of voters as an activity of a person or group of people to participate actively in political life, among others by choosing the leader of the country and directly or indirectly influence the policy of the government (public policy).

\section{The Rational Voter Actor}

The rational approach focuses on voter action either individually or in groups in performing an action to participate or exercise the right to vote which in principle leads to the desire to choose because of the basic purpose of course Rational voters in the view of the Regional Head Election, put forward the value approach related to political options individually. The willingness of the individual conveys their right to vote, because it is based on the consciousness to convey their right to vote.

The rational choice theory of Coleman is evident in the idea of essentially that "individual actions leads to something of the purpose and that purpose (and actions) is determined by the value or options (preferences)" (1990:13). To give an analogy in the realization of his theory Coleman uses two main elements, namely the actors and resources is something that attracts attention and can be controlled by the actor.

\section{RESEARCH METHODS}

The research used is qualitative, that is a research that produce descriptive data in the form of speech or writing and behavior that can be observed from people (subject) itself. The primary source of data is the data that is retrieved directly on a resource person or respondents are concerned. The research informants are fishermen women who live in Panimbang village. Data collection techniques obtained through direct research activities to the location to find the complete data and related to the problem under study. This data collection technique is done by observation, interviews on women voters who are domiciled in Panimbang and housewives. In this research will be conducted in-depth interviews to the women households who have been involved in the campaign and who are not involved in the election campaign, but have voting rights. Documentation is also performed as supporting data that are considered important for strengthening data analysis.

\section{RESULTS AND DISCUSSION}

\section{A. The Characteristics Of Pandeglang Regional Head Election}

The holding of District Head and Deputy Regents election is part of the strengthening of democracy at the regional level. One of them is the election of Regent and deputy regent of Pandeglang which was held in 2015 which was conducted simultaneously in Indonesia. Election of regional heads in Indonesia has been conducted simultaneously twice, ie in 2014 and 2015. While Pandeglang participate in the election of regional heads simultaneously in the second period. The holding of Pandeglang Regional Head Election in 2015 number of Permanent Voters List (DPT) based on Pandeglang General Election Commission (KPU) data of 2015 amounted to 958,178 . Of the total number of DPT the voters are male sex of 489,504 female divergent voters in the amount of 468,674 . while for elections Panimbang District that is equal to 38,042 male gender 19,047 and Female voters vote of 18,995 voters.

Voting result based on spouse at regional head election held in pandeglang Three pairs of candidates for 2015 election in Pandeglang Regency obtained the following votes: Aap Aptadi-H. Dodo Juanda (independent line) earns 103,296 votes; Irna Narulita-Tanto W Arban (party supporting PPP, PKB, Gerindra, Golkar, Hanura, PKS, PAN, PBB and PKPI) = 367,547 votes in Panimbang 367,547 votes; Hj. Ratu Siti Romlah- Yan Riadi (party supporters Democrats, PDIP, and Nasdem) get votes 58,438 Data Source KPU Pandeglang 2015. Based on the data acquisition of votes then KPUD Pandeglang has set the serial number of Regent and Vice Regent Candidate Pandeglang No. 2 Irna Narulita-Tanto W. Arban as Pandeglang regent period 2016-2021 as the winner with the highest number of votes. Based on that number Narulita as a female candidate gets the highest votes exceeds the number of votes with other candidates. Irna Narulita is also a member of DPR-RI period 
2014-2019 and has been participated in elections of regional head of Pandeglang regency in previous period.

Participation of voters in the election of regional heads in Pandeglang District, about 60\% who directly involved gave the right to vote. The participation of women voters in Panimbang is estimated to be around $25 \%$ participating in giving their voting rights. as there are various women's participation in democratic party processes at the local level. This suggests that the presence of women in political participation has increased the role of women in political power. This is indicated by the fact that women are also enthusiastic in participating and supporting the implementation of elections in 2015.

\section{B. Characteristics of Women's Voters in Panimbang}

The implementation of the Regional Head Election (Elections) Pandeglang, involvement of women in providing their right voice, actually not seen due to prospective women, but voters already feel has an invitation from the organizers of the KPUD Pandeglang to come to the polls. As YUN informant (35 years old) said that his participation actually gave his voting rights in the regional head election in Pandeglang, because he felt called by his conscience and also had received an invitation from the organizers, and also already know the polling schedule set by the organizer.

The education of women fishermen in Panimbang, most of them are educated graduates of elementary school. Based on interview data from several informants it was revealed that women did not continue their education to the next level, because of internal and external encouragement factor. Encouragement of internal factors, because women assume that education is not directly related to their work. While external factors, the absence of encouragement from parents and those around them. In addition, motivational factors from peers do not exist. Unlike the case today's children are already there who continue to high school level, and it happened since the 2000s.

Based on the informant's statement, it is described that the presence of voters in the regional head election in Pandeglan 2015. Support that, strengthened again because it has an invitation. Stages of organizing, it is known both day and date of the election of Pandeglang regent. The involvement of women in the election of the Pandeglang Regent, actually arose because of the awareness and the desire to convey the right of his voice. The existence of organizers also in Pandeglang District continue to socialize, especially in coastal communities.

In the tradition of local election, the presence of female candidates must work twice as hard as the male candidate. Therefore, the patriarchal culture that was built in the community Pandeglang still make the strength for men when compared with women. In addition, women candidates still have an indication of weakness in identity politics, especially in terms of bonding primordialism. Such bonding conditions, often cut the chances women candidates advance in elections and legislative elections.

The pattern of campaigns in the election of regional heads in the fishing village, among women is done through the approach of recitation of mothers on a weekly basis. Prospective women in local elections in Pandeglang often get a chance to compete, such as in previous elections Heryani became vice regent of 2010-2015 period accompanied Pandeglang Regent Erwan Kurtubi. Similarly, the Regent who won the current period 2015-2020 Irna Narulita, had participated in the 2010 election as candidates for Regent Pandeglang.

Political cadre for candidates for leadership in Pandeglang District, there are actually prepared cadres. The appearance of women as candidates for regional heads and legislative candidates in pandeglang, can't be released because of the strength of men behind it. Because all the women candidates who emerged as candidates for candidates for Regent and Vice Regent of Pandeglang, because reinforced by the background of his family or the people around him as a politician.

Basically, gender is not a measure in measuring the opportunities and opportunities of a candidate. In terms of ability and intellect, women politicians have a reliable ability, but candidates who appear in Pandeglang have a background of his family as a politician. For example Heryani, her husband is $\mathrm{Tb}$ Chasan Sohib (alm) is a Banten figure and also the parents of former Banten Governor Ratu Atut Chosiyah, also Regent Serang Ratu Tatu Chasanah who are all female leaders cadres. While Irna Narulita is the wife of Pandeglang Regent in the previous period 2005-2010, H. Dimiyati Natakusumah who is currently a member of DPR-RI.

The presence of prospective leaders among women in Pandeglang in fact, the community can receive and support it in the election. For that, women activists who have a politician background do not want to lose the opportunity in every moment of the election event. The political character of Pandeglang, still highly patriarchal, has received recommendations from certain circles and the background of parents or families around them to seize the leadership seat. Women's leadership in Pandeglang, always supported by the people and not only among women, but from among men also provide support to the candidates for female heads of regions.

\section{Awareness Factors Importance of Giving Voting Rights}

Figure Labels: Use 8 point Times New Roman for Figure labels. Use words rather than symbols or abbreviations when writing Figure axis labels to avoid confusing the reader. As an example, write the quantity "Magnetization," or "Magnetization, M," not just "M." If including units in the label, present them within parentheses. Do not label axes only with units. In the example, write "Magnetization $(\mathrm{A} / \mathrm{m})$ " or "Magnetization (A ( m(1)," not just "A/m." Do not label axes with a ratio of quantities and units. For example, write "Temperature (K)," not "Temperature/K."

Women's political quota based on the Act is $30 \%$ of the nomination of legislative members. The application of the provisions of women has a $30 \%$ quota to engage in politics, as contained in Article 65 paragraph (1) of Law of the Republic of Indonesia Number 12 Year 2003 on General Election of Members of DPR, DPD and DPRD that every political party participating in the General Election may nominate, Provincial DPRD and Regency / City DPRD for each electoral district 
with regard to women's representation of at least $30 \%$. Through this regulation, the passion and motivation of women to engage directly in politics is very high. Both become legislative members, as well as participate in the nomination of regional head and deputy head of region.

After the reform era, elections in 1999, women's interests have begun to engage directly in the polity, including the election of regional heads. At least there is a general view on the importance of encouragement of women's participation in politics that must be contained in the Act. As Mina (42 years) said that: "Indeed the current conditions, women have joined the political plunge, including the election of regional heads in pandeglang. Women's political representation contributes more votes than men. Pandeglang also during this time most men nominate the head of the region, but in the election of regional heads in 2017, Irna Narulita elected head of the region from among women. The election of Irna Narulita, is not only women who choose, but men too much choose. It can be proved by the number of men directly involved into successful teams". (Interview, February 2, 2017)

Based on the results of the interviews, it was revealed that the process of democratization that runs in Indonesia up to the regional level, has now progressed in terms of appreciation aspects of the political rights of citizens through the general election of regional heads in Pandeglang regency. The political climate implications in Pandeglang experience an individualized voting rights system for women. Support of local political building for women, formed for socio-cultural support of society and constitution.

The strategic position held by women's voter groups is always followed by factors that underpin the behavior of voting. Women voters are then associated with a model of political participation and rationalization of the use of suffrage in Pandeglang, with the view that women deserve to be leaders in pandeglang. This is the strengthening of women's political interests through various approaches through recitation and strengthening of political constitution rights for women in Pandeglang district.

Before the enactment of women quota as much as $30 \%$ of women in the management of political parties is still low. As observations made in the fishing village prefer to position themselves not to vote and not even take sides with women candidates. Based on informants because they have limited education both formally and socially in the field of politics and their knowledge of the value of democracy adopted today. Sajogyo P (1983: 46) During this time women only have a role in domestic or domestic work and even have an influence in the decision-making process officially made by men.

The conditions of women's activities in domestic terms, but still they have awareness in terms of participation to convey their voting rights individually through the election of regional heads. elections of regional heads (elections) held in 2015, according to informants that women individually have an understanding of the importance of participating in the election process as part of political circles in the region. Although women do not directly engage in practical politics, they know that voting is part of the rights of individuals protected by the state.
For some women voters who already understand the world of politics, it has its own segmentation, so it is not uncommon for them to make choices according to the rational choice or the assimilation factor, as Hungtington (2003: 166) The group's ability to adapt in a system in releasing values . As Panimbang determines the political choice chosen by its peergroup or peer group. In addition to political trend factors and peergroup options, female voters usually use the right to vote as a parent or choice of choice from their husbands.

The presence of candidates for heads of regions through social activities or spiritual activities held in Panimbang village, have a positive impact on the importance of choosing regional heads. All candidates who participated in the Pandeglang Regent's elections market in 2015, visited Panimbang in order to introduce themselves and encourage people to vote. The activity of the political visit was actually accompanied by a group of social organizations that voiced women's rights amidst the rise of women in the regional head elections. Through the women's struggle, it was practically fruitful in Panimbang with Irna Narulita's winning vote at Panimbang winning, which according to Irna Nrulita informant is estimated to get around $40 \%$ support compared to the other candidates.

Ability of assimilation of Irna Narulita among men group through various activities, including development of fisherman infrastructure and give promise to improvement of fisherman welfare if later elected. Some fisherman informants said that Irna Narulita often visited Panimbang, actually not because as a candidate for regional head, but Irna has visited since her husband became regent Dimiyati Natakusumah. In addition, Irna also became a member of the House of Representatives of the period 2014-2019 and earned a vote in the village Panimbang.

\section{Active Factors Listening to Successful Candidate Team Information}

Women who want to get involved in the world of politics, in reality and regulation Act on political parties actually strongly support women with $30 \%$ quota. Specifically, the political environment is very open for women to fight in the leadership and parliamentary seats. Kenya, the political system in Indonesia provides full support for women. On the contrary, for patriarchal supporters, from the cultural and local aspects of women, women are not given the widest opportunity, because women are considered to have weaknesses in terms of daily activities in the household.

The conditions in pandeglang differ from that reality, because the cadre of prospective leaders among women is still running well. As the statement Nuraeni (politician) said that: "regeneration of women in the political party environment get a very good position. The proof of many women who represent women in the parliamentary seat both at the level of Parliament Pandeglang and in kusri DPRD Banten Province. The women's view as a member of the legislative election result in 2014 is not really because of the background of their parents or relatives, but because they have the ability and strength of the mass base in political activities (Interview, February 12, 2017)". 
Based on the statement, that in pandeglang women's involvement in politics, get a strategic position, although pandeglang is a religiously Islamic region, but women do not experience difficulties. Women's activeness in the political stage, has an influence on the presence of women vote on the implementation of elections. Female investment as well as prospective heads of regions among women certainly provide education to other women. Women's interest in conveying their voting rights in elections is not a matter of women or men, but the approach is massive and well socialized.

Election of regional heads in Pandeglang especially among women, has long been well socialized. As Sugiyah's statement (52th) revealed that: "Candidates for regional heads are held in each election, usually long before the election has been made, which enters the Binuagens Fishermen's shelters, whether male or female. Once designated as a candidate for Regent, usually the candidate more often toured in Binuangen village to review the market and place the auction and ask the condition of the fisherman. The guidance done by the candidate of regional head is usually dialogue with fisherman and conducting routine recitation, because Panimbang region is an Islamic region relegius (Interview result, January 2, 2015)".

Based on the interview, revealed the socialization of the successful team of regional head candidates during the determination by the election organizer, the candidate has officially held more coordinated socialization with the community nodes in Panimbang. The presence of successful teams in the community, is actually a political tradition in the elections to socialize candidates through a representative approach. Socialization is done to convey the desire of his candidacy and simultaneously seek sympathetic from the people who will vote.

The election of regional heads of women in the Panimbang Village area, is not really because the voters are fanatical or not fanatical to choose men or women. The election of regional head, actually can be seen also commitment in conveying solution to society desire in Panimbang. The proximity between voters and the community is very important, so that the voters know more and know the candidates to be chosen based on commitment and closeness.

The proximity factor between the candidate and the community is very important that the social contract in the form of work program can be in line with the wishes of the community. Proximity of candidates can be done by successful teams that have formed as a group that mensosilisasikan prospective head of the region, as expressed Darmin (42 years) that:

Proximity of candidates for head of region with voters, can be done by a successful team. I only once met the candidate, Irna Narulita's mother, but her successful team is very diligent to meet with us and approach, either personal or small group with fisherman. Approach is actually done just greet and attention about our fate. In the election of regional head I choose bu Irna Narulita, because the success team also exist in this fishing village.

Based on the interview, it was revealed that the election of candidates for regional heads can be done through the assistance of successful teams who directly meet with the prospective voters. Approach the local chief team's success to greet and make a special approach to convey the purpose and objectives based on the vision of the mission of the candidate head of the region. The approach taken so far is more on social and community activities. Frequent approach, in the community both in the area of fishing village and outside the fishing village.

In reality it is found that the participation of women in conveying their voting rights in the election of Pandeglang Regent 2015, because of their own encouragement and willingness. The emergence of that impulse, actually caused by the closeness between the community and the candidate. The proximity factor was due to the frequent candidates of the Head of Region visited the fishing village of Panimbang. pilkada indeed because of its own consciousness. The proximity between the candidate and the female voters is also due to the candidate's background.

The presence of the team in delivering the work program in the presence of fishermen women in Panimbang, actually not very significant given the response by women fishermen. Especially if the mission vision in written form, because most of the fishermen's wife cannot translate what is contained in the vision of the mission. Because women in Panimbang have very low education degrees, so mission vision in written form will have no influence in translating what the candidate wishes.

Participation of women in conveying their right to vote in the election, it is important that women's participation in the election is high enough, it can be known from the awareness of the women to participate in the election of regional head and deputy head of region. As informant Anna (31 years) said that:

That the involvement of women in choosing it because of the will, maybe also because there is no job, so better choose and enliven the election of regional head. Participation of women vote on election pandeglang for seeing candidates. Indeed, not all chose Mrs. Irna, but the majority of the conversations of housewives, more likely to choose Mrs. Irna. It is a secret vote, and should not be told to anyone, but the presence of Mrs. Irna in Panimbang has been several times.

The presence of regent candidates in Panimbang, has actually already ever been visited, but Mrs. Irna several times to Panimbang. That is, it can happen because Mrs. Irna Narulita is a member of legislative of DPR-RI and also she is wife of Dimyati Natakusuma, who has been serving Pandeglang Regent for 2 periods.

\section{CONCLUSION}

1. Characteristics Women's political participation in elections in Panimbang Pandeglang district is more emphasized because of active awareness in political activities. Although women are not involved in campaign activities and socialization of candidates for regional head. The livelihood of women fishermen in the elections can be seen in the presence of active voter registration.

2. Factors driving the participation of women in the elections, because the work is not too busy at home, so still 
have time for recitation and dialogue organized social institutions and or government-related politics. Although not directly involved in practical, but still follow the progress of the election schedule either through her husband, neighbors and even from government elements.

\section{SUGGESTION}

1. Require each political party to make efforts to increase women's participation, especially among fishermen households, consistently through dialogue and study groups.

2. To socialize the importance of ensuring equal access and participation of women in every political party, continuously improving the quality of women's human resources, especially in the case of election of regional head and Legislative election.

\section{REFERENCES}

[1] Friedman D.and M. Hechter, 1988, The Contribution of Rational Choice Theory toMacrosociological Research, Sociological Theory.

[2] Huntington P. Samuel. 2003. Tertib politik ditengah pergeseran kepentingan massa, Raja Grafindo Persada, Jakarta

[3] Coleman S. James. 2008. Dasar-Dasar Teori Sosial. Nusa Media: Bandung

[4] Moleong, Lexy J, 2007,Metodologi Penelitian Kualitatif, Bandung: PT Remaja Rosdakarya.

[5] Surbakti, Ramlan. 1999. Memahami Ilmu Politik.Grasindo. Jakarta.

[6] Law of the Republic of Indonesia Number 8 Year 2012 on General Election of members of House of people's representatives, Assembly at provincial, and Leadership of political party at provincial. 